
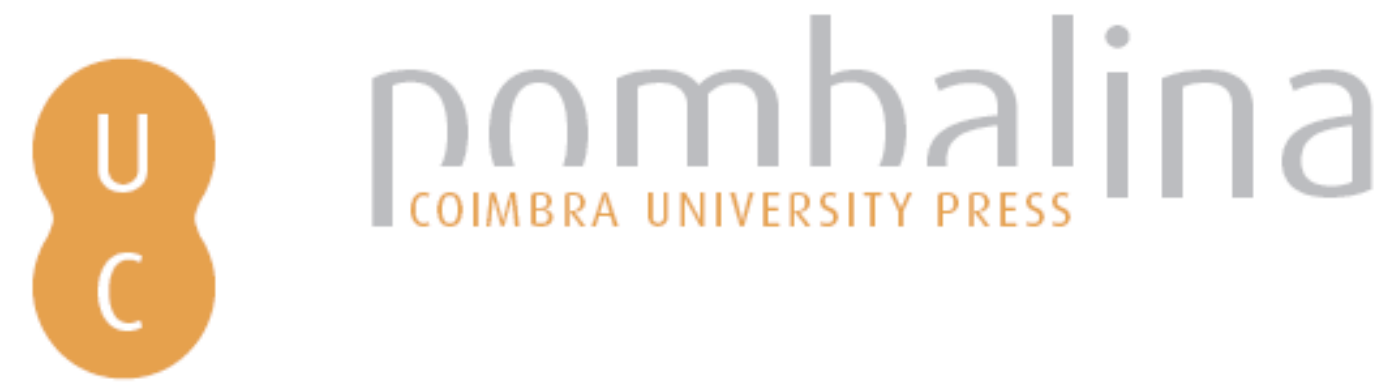

\title{
National scenery of the use of genetic identification technique in the official services of identification and the dentist participation
}

\author{
Autor(es): $\quad$ Oliveira, R. N.; Baraldi, A. M.; Menezes, L. M. Bezerra de \\ Publicado por: Imprensa da Universidade de Coimbra; International Academy of Legal \\ URL \\ persistente: \\ Medicine \\ DOI: \\ URI:http://hdl.handle.net/10316.2/31771 \\ DOI:http://dx.doi.org/10.14195/978-989-26-0173-1_23
}

Accessed : $\quad$ 26-Apr-2023 14:01:22

A navegação consulta e descarregamento dos títulos inseridos nas Bibliotecas Digitais UC Digitalis, UC Pombalina e UC Impactum, pressupõem a aceitação plena e sem reservas dos Termos e Condições de Uso destas Bibliotecas Digitais, disponíveis em https://digitalis.uc.pt/pt-pt/termos.

Conforme exposto nos referidos Termos e Condições de Uso, o descarregamento de títulos de acesso restrito requer uma licença válida de autorização devendo o utilizador aceder ao(s) documento(s) a partir de um endereço de IP da instituição detentora da supramencionada licença.

Ao utilizador é apenas permitido o descarregamento para uso pessoal, pelo que o emprego do(s) título(s) descarregado(s) para outro fim, designadamente comercial, carece de autorização do respetivo autor ou editor da obra.

Na medida em que todas as obras da UC Digitalis se encontram protegidas pelo Código do Direito de Autor e Direitos Conexos e demais legislação aplicável, toda a cópia, parcial ou total, deste documento, nos casos em que é legalmente admitida, deverá conter ou fazer-se acompanhar por este aviso.

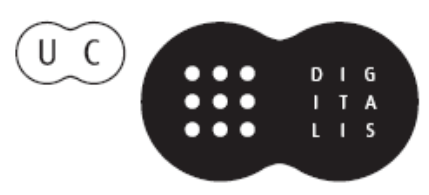




\section{Duarte Nuno Vieira Anthony Busuttil \\ Denis Cusack • Philip Beth}
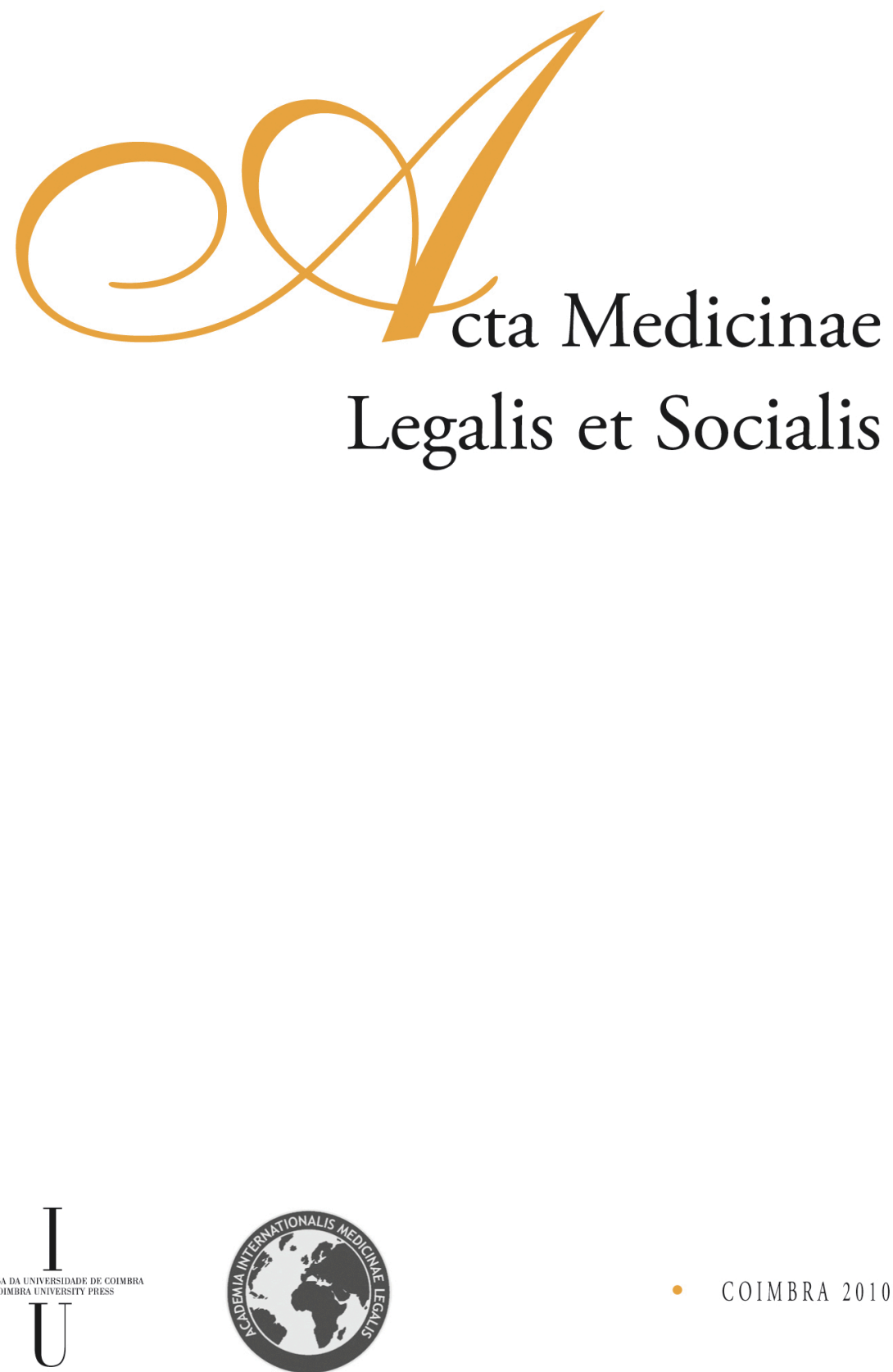
R. N. Oliveira ${ }^{1}$, A. M. Baraldi ${ }^{1}$, L. M. Bezerra de Menezes ${ }^{2}$

${ }^{1}$ Department of Social Dentistry, School of Dentistry, University of São Paulo, Brazil

${ }^{2}$ Federal University of Ceará, Brazil

\title{
NATIONAL SCENERY OF THE USE OF GENETIC IDENTIFICATION TECHNIQUE IN THE OFFICIAL SERVICES OF IDENTIFICATION AND THE DENTIST PARTICIPATION
}

\begin{abstract}
DNA analysis can be considered a major technical advance in criminal investigation since the discovery of fingerprints. It is incorporated in forensic routine by police of first world countries and now it has been used in forensic reports in some states of Brazil. This paper aimed to know the Brazilian context regarding this technology. Questionnaires were applied in Institutes of Criminology and DNA forensic laboratories of 20 Brazilian states. The results of this study allowed us to verify the greatest influence of DNA technique in identification processes, the professional diversity of teams and the description of the procedures, which incorporated specific knowledge from dental professionals in the examples of teams with the presence of dentists.
\end{abstract}

Keywords: forensic DNA; forensic dentistry; human identification; dental DNA.

\section{Introduction}

Post-mortem human identification is an extensive study and research area in Forensic Dentistry, a science that has been evolving in a highly significant way. It used to be based on simple methods of observation and comparison and nowadays it employs sophisticated laboratory tests, including genetic exams (OLIVEIRA $\left.{ }^{8}, 2008\right)$.

The analysis in molecular biology was introduced in forensic context and started to be used by forensic experts, dental professionals, and forensic doctors. They are associated with classical forensic techniques and result in more objective and reliable reports (SILVA et al. ${ }^{10}, 2007$ ).

However, the introduction of new technologies in human identification services depends on financial resources available in each state for the acquisition of equipment and/or adaptation or construction of infrastructure. Moreover, there is the necessity of creating or negotiating the nursing staff and updating techniques in order to work with new methodologies (OLIVEIRA $\left.{ }^{8}, 2008\right)$.

Thus, the mapping of the states that have already benefitted from the use of forensic DNA allows the understanding of the Brazilian context regarding that new technology, its implantation, structure, applied methodology, the categories of professionals, showing the differences in several units spread all over the country. 


\section{Objective}

This study aims to verify the influence of the DNA technique in the identification processes in Brazilian identification services, checking the diversity of professionals involved in the analysis and the most common procedures.

\section{Material and method}

A questionnaire was used in data collection with the aim of establishing the centers that use DNA technique in forensic identification, types of biological samples, the existence of accreditation certificate in laboratories, number of procedures, category of professionals that belong to the team of forensic DNA, the number of dentists in the identification institutes and how many professionals work with forensic DNA.

The questionnaire was applied during the year 2008 with the of interviews with the experts who were responsible for the identification process by means of personal contact that happened during scientific events in the area, or in a complementary way after this first contact by means of telephone and/or e-mail.

\section{Results}

Contact was established with the Central of Legal Medicine Institutes in capitals of the 26 Brazilian states besides the Federal District. The questionnaire was answered by 20 Institutes and in 3 states the data were not incorporated in the discussion since the service in Rondônia was being implanted; joint venture was being renovated between Civil Police and the Federal University in Alagoas - the exams were temporarily being conducted in Bahia. The State of Pernambuco informed that it did not own a DNA laboratory and had the collaboration of the States of Paraíba and Bahia.

The States of Amapá, Amazonas, Pará, Roraima, Tocantins, Bahia, Ceará, Maranhão, Paraíba, Piauí, Rio Grande do Norte, Goiás, Minas Gerais, Rio de Janeiro, São Paulo, Paraná and Rio Grande do Sul have effectively contributed to the analysis.

The States of Acre, Sergipe, Mato Grosso, Mato Grosso do Sul, Espírito Santo and Santa Catarina; besides the Federal District did not answer or refuse to answer the questionnaire.

From the 20 States that were initially part of the sample, the dental professinal is present in 11 (Amapá, Bahia, Rio Grande do Norte, Pará, Goiás, Tocantins, Rio Grande do Sul, São Paulo, Paraíba, Minas Gerais and Paraná).There is also one professional linked to the DNA laboratory in Minas Gerais and Bahia and two others in Paraíba ( Graphic 1).

The DNA forensic team from the 17 States that had already implanted the service by the late 2008 consisted of 83 professionals: 37 pharmacists (44\%), 31 biologists (37\%), 08 biomedical doctors (10\%), 04 dentists (5\%), 02 chemists (3\%) and 01 doctor (1\%) (Graphic 2).

The type of biological sample depends on several factors, such as the condition of conservation of the donor of this sample, the type of crime. Blood is the most employed biological sample (39\%) (Graphic 3). 
In most cases $(60 \%)$, that biological sample comes from sexual crimes (Graphic 4).In spite of that fact, in $43 \%$ of the states, the collection of saliva in bite marks, when present, is part of the forensic examination (Graphic 5). This exam is usually performed by forensic doctors, and there are no dentists responsible for this procedure in the States involved.

Regarding accreditation in the 17 operating laboratories by the late 2008, 15 of them have answered the questionnaire, and 8 affirmed not performing any tests and 7 performed tests in association with the Brazilian Genetic Society, the IberoAmerican Working Group in DNA analysis or the Spanish and Portuguese Group of the International Society of Forensic Genetics.

The number of DNA exams performed until December 2008 has varied in each State from ten to more than three thousands summing up 9.480 exams. The DNA analysis services have been implanted since 1998 in Minas Gerais; 1999 in Rio Grande do Sual and Goiás; 2000 in Paraná and Pará; 2001 in the State of São Paulo; 2004 in Paraíba; 2005 in the States of Rio de Janeiro, Bahia and Roraima; 2006 in Maranhão and Amapá; 2007 in Amazonas, Rio Grande do Norte and Ceará and 2008 in Tocantins and Piauí.

\section{Discussion}

The particularity of this research when interviewing forensic official services has brought some difficulties and, due to this fact, some States did not participate, since the hierarchic characteristic of those services does not provide autonomy for their professionals to release data without the approval of those in charge. Regarding the States that did not provide information, it is known that Mato Grosso, Espírito Santo and Santa Catarina, besides the Federal District, own laboratories of DNA forensic analysis.

The relation between the dentist and molecular biology and their presence in the official services of human identification can be traced back to the Law 5.081/66, from August 24 1966 (BRASIL $^{\text {th }}, 1966$ ), in its article 6o, that defines the dentist's competencies in: I - practice all the acts regarding Dentistry, derived from acquired knowledge in under-graduate or graduate courses;

IV - perform dental forensic exams in civil, criminal, labor relations and in administrative office.

It is worth citing The Resolution CFO-63/2005(Conselho Federal de Odontologia ${ }^{4}$, 2005) that ruled in its $64^{\text {th }}$ article the areas of performance of the Forensic Dentistry professional, among them:

"Human identification; reports in correlated evidence, including spots or fluids originated or present in oral cavity."

The forensic techniques applied to human identification are methods that produce fully reliable results (SILVA et al. ${ }^{10}$, 2007).

The dentist who is introduced in the forensic context can be really helpful in situations where the corpse is skeletonized, carbonized or in advanced state of decomposition (SILVA et al. ${ }^{11,2008) . I n ~ t h e ~ p r e s e n c e ~ o f ~ b i t e ~ m a r k s, ~ i t s ~ p r i m a r y ~ f o r e n s i c ~}$ approach is related to the analysis of dental characteristics presented in the victim's 
injury or in the object found at the crime scene. However, when those characteristics do not produce satisfactory results, the DNA analysis obtained from the cells that are present in the oral cavity and collected from the bite mark consists an important phase to determine the individual's identity that has produced the evidence(ATSÜ et al. ${ }^{1}, 1998$; MCKENNA et al. $\left.{ }^{6}, 2000\right)$.

The multidisciplinary character of DNA forensic exams has its evidence in the presence of six different professional categories that compose the functional staff of those services and that, according to BILGE et al. ${ }^{2}$ (2003), several techniques are used to identify a corpse in complex cases.

Despite the teeth are not the biological sample of election, they appear among other biological samples as important factors in the identification process and criminology due to the high probability of the dental characteristics that are never the same in two individuals, as well as relatively high level of physical and chemical resistance of the dental structure(OLIVEIRA $\left.{ }^{8}, 2008\right)$.

In those situations, the teeth act as elective material to analysis and the extraction of the deoxyribonucleic acid (DNA) is obtained by the dental pulp, or by the tooth itself. This is due to the hardness of dental structures (enamel, cement, dentine and the alveolar bone around the tooth) that provide conditions to DNA preservation and integrity even in adverse environmental circumstances such as high temperatures (Tsuchimochi et al. ${ }^{13}$, 2002).

The association of classical forensic techniques in genetic exams has allowed significant evolution in forensic reports. Case investigations of sexual violence that were once limited to semen analysis of the sample, serological tests, such as blood testing , are nowadays able to produce accurate results with the possibility of analyzing genetic material extracted from fluids, capillary bulb and fetal material(GOES et al. ${ }^{5}$, 2002; SILVA et al. ${ }^{9}$, 2004).

The results reaffirm the fact that sexual violence is the one that mostly employs techniques of genetic investigation, however, human bite marks, evidence that is frequently found in such crimes, are discarded by a great number of institutes. DNA from saliva found in those bites is sometimes fundamental to find the aggressor (Sweet et al. ${ }^{12}$, 1997).

In a study, Walsh et al. ${ }^{14}$ (1992) proved the efficacy of human saliva as an adequate biological material to forensic analysis after evaluating the reliability of DNA extraction in different biological materials, including saliva and saliva spots.

If compared to blood puncture, saliva presents advantages since it is simple to collect biological samples and it presents less probability of contamination. It is a non-invasive, painless and non-traumatic method and in cases of paternity, children are able to collaborate with it (NICOLÁS; CANELA7 , 1999).

Regarding laboratory accreditation, one may observe low adherence in services possibly because such tests have not been mandatory yet in Brazil and there are not representative organizations to apply those tests. A second motive derives from the fact that official services are subjected to public trust. Anyway, proficiency from international organizations such as GEP-ISFG gives credibility to the tests and protects the Institution in case the results are contested.

Contribution of every State in the sum of exams performed varies and reflects the chronological differences in service implementation. 


\section{Conclusion}

The techniques of genetic identification are important tools introduced in forensic practice to solve questions that were once considered unsolvable to Criminalistics, Medicine and Forensic Dentistry. The multidisciplinary character of the forensic practice and the experience of fewer States where the dental professional has already been practicing in the DNA forensic team suggest that the presence of a dental professional in the team is fundamental.

\section{Acknowlegment}

Project was supported by FAPESP (Fundação de Amparo à Pesquisa do Estado de São Paulo) process 07/02913-2.

\section{References}

1. Atsü SS, Gökdemir K, Kedici PS, Ikyaz YY. Bitemarks in forensic odontology. J Forensic Odontostomatol. 16:30-34, 1998.

2. Bilge Y, Kedici PS, Alakoç YD, Ûlküer KÛ, Ilkyaz YY. The identification of a dismembered human body: a multidisciplinary approach. Forensic Sci Int. 137:141-46, 2003.

3. Brasil. Decreto lei no 5081, de 24 de agosto de 1966. Regula o Exercício da Odontologia. Diário Oficial da União, Brasília (DF) 1966 ago. 26.

4. Conselho Federal de Odontologia. Resolução CFO-63/2005. Consolidação das Normas para Procedimentos nos Conselhos de Odontologia. Brasília (DF).

5. Goes ACS, Silva DA, Domingues CS, Sobrinho JM, Carvalho EF. Identification of a criminal by DNA typing in a rape case in Rio de Janeiro, Brazil. Sao Paulo Med J. 120:77-80, 2002.

6. McKenna CJ, Haron MI, Brown KA, Jones DAJ. Bitemarks in chocolate: a case report. J Forensic Odontostomatol. 18:10-14, 2000.

7. Nicolás OS, Canela PR. Restos biológicos de interés forense. In: Jarreta MBM. La prueba del ADN en medicina forense. Madri: Masson; 1999.

8. Oliveira RN. Incorporação de Novas Metodologias à Odontologia Legal: Aplicação dos Recursos da Biologia Molecular [Tese de Livre-Docência]. São Paulo: Faculdade de Odontologia da USP; 2008.

9. Silva DA, Goes ACS, Carvalho JJ, Carvalho EF. DNA typing from vaginal smear slides in suspected rape cases. Sao Paulo Med J. 122:70-72, 2004.

10. Silva RF da; Pereira SDR; Daruge-Júnior E; Barcelos RSS; Godinho, NMO; Souto R. Genetics and molecular biology: a literature review of forensic dentistry application.Braz J Oral Sci. 6(20):1254-1259, 2007.

11. Silva RF, Daruge Júnior E, Pereira SDR, Almeida SM, Oliveira RN. Identificação de cadáver carbonizado utilizando documentação odontológica. Rev. odonto ciênc. [periódico online] 23(1):90-93, 2008. Disponível em: URL: http://revistaseletronicas.pucrs.br/ojs/index.php/ fo/article/viewFile/1245/2881 [2008 nov. 23]. 
12.Sweet D, Lorente M, Lorente JA, Valenzuela A,Villanueva E. An inaproved method to recover saliva from humam skin: the double swab technique. J Forensic Sci. 42(2): 320-2, 1997.

13. Tsuchimochi T, Iwasa M, Maeno Y, Koyama H, Inoue H, Isobe I, Matoba R, Yokoi M, Nagao M. Chelating resin-based extraction of DNA from dental pulp and sex determination from incinerated teeth with Y-chromosomal alphoid repeat and short tandem repeats. Am J Forensic Med Pathol. 23(3):268-71, 2002.

14. Walsh DJ, Corey AC, Cotton RW, Forman L, Herrin GL, Word CJ, et al. Isolation of deoxyribonucleic acid (DNA) from saliva and forensic science samples containing saliva. J Forensic Sci. 37(2):387-395, 1992.

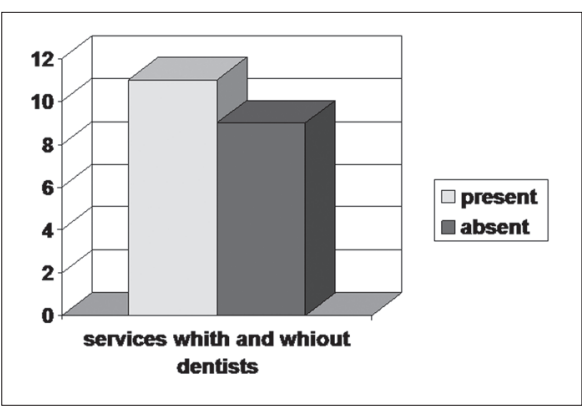

Graphic 1 - Presence of a dentist in Criminalistic Institutes

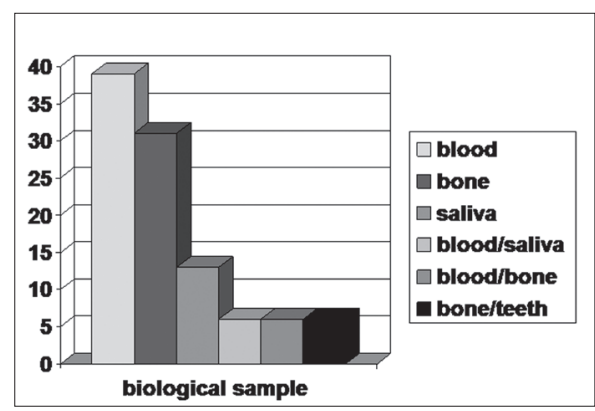

Graphic 3 - Biological sample of election

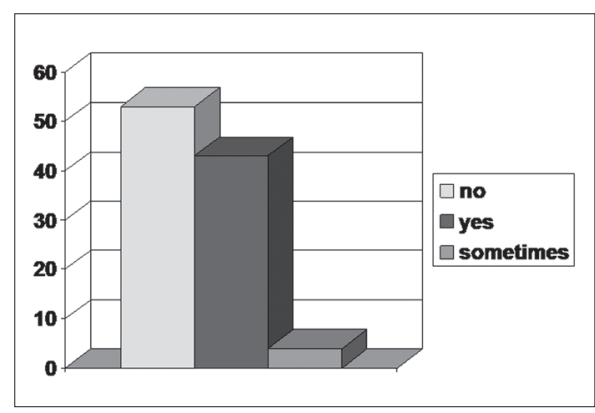

Graphic 5 - Performance of suabe in bite marks

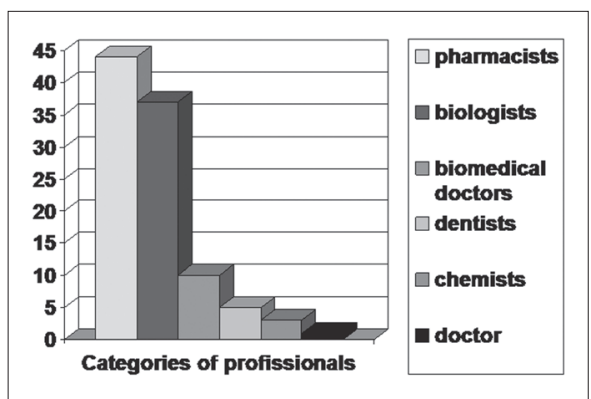

Graphic 2 - Categories of profissionals present in the DNA forensic team

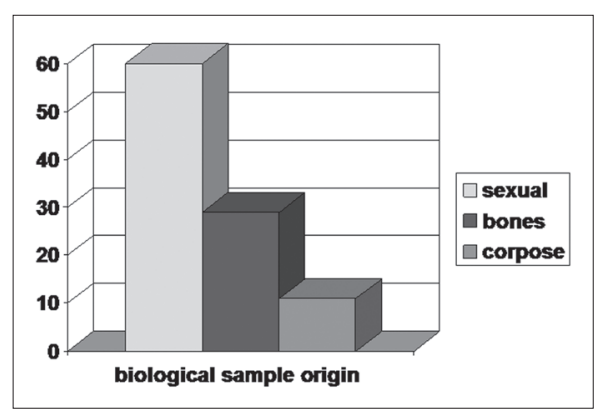

Graphic 4 - Biological sample origin 